\title{
Longing for economic growth without current account deficit: Chinese model
}

\author{
Deniz Züngün ${ }^{1}$
}

\begin{abstract}
After 1978, China implemented some reforms and branched out to foreign countries. China, applying a strategy based on export and keeping its domestic currency, Yuan, in balance during this process, has increased its economic growth. However, current value increase in dollar and global fluctuations has also affected the growth in China. Considering the fact that growth and current account balance is one of the most important variables of a nation, it is an issue of concern how the decreasing economic growth rate of China in 2015, compared to previous years, will affect the current account balance. Thereby, this study examines the effect of Chinese growth, with the application of export based industry strategy, on the current account balance between the years of 2000-2015. As a result of the study, a bidirectional relation is determined with Granger Causality Test between economic growth and current account balance. During the Regression Analysis, it is ascertained that $1 \%$ of increase in economic growth will incur $0.32 \%$ of increase in current account.
\end{abstract}

Keywords: Economic Growth; Current Account Balance; Time-Series Analysis; Granger Causality Test; Regression Analysis.

\section{Introduction}

One of the main variables related to the macro-economic structure of a nation, current account balance is a group of account, in which flow of funds, transacted via purchasing or selling services or financial assets between countries, is displayed. Within the current account balance, current surplus occurs as a result of excess in unrequited transfers due to the fact that goods and service export is more than the import and due to increase in investment income. Current deficit, on the other hand, occurs as a result of excess in unrequited transfers to other countries due to the fact that goods and service import is more than the export and due to decrease in investment income (Seyidoğlu, 2003: 404-410).

Another important macroeconomic indicator in economy, economic growth is defined as the increase in final goods and service quantity produced in a nation within a certain period (Kibritçioglu, 1998: 1). Economic growth is a prominent way for people in a nation to increase their quality of life. Thereby, main macroeconomic aim of all countries is to perform a balanced economic growth. While the microeconomic factors affected by or affecting economic growth differ, its relation with current account balance is one of the most investigated subjects lately.

Since the early ages of history, people tried to get by with the limited natural resources in order to meet their endless needs. In accordance with this aim, nations improve their economy via various political strategies and try to become self-sufficient and they are in the way of taking steps for being the power group particularly in terms of economy. Although each nation had different effort in this, reaching to a determined aim has always remained in the agenda in every age and all

\footnotetext{
1 Assist. Prof. Dr., Manisa Celal Bayar University, Ahmetli Vocational School, Department of Human Resource Management, zungund@hotmail.com
} 
around the world. Especially with the reform started in 1978, China developed quickly and became the center of world-wide economic agenda. Until 30 years earlier, China had a closed economy system and exchange rate of national currency was determined by the government and the control of its centralized regime blocked international trade. Additionally, due to the fact that China did not have an outward-oriented economic structure besides not having a capital market to meet the Chinese financial need, it was impossible for China to become indebted to international market or institutions, allow foreign investment or invest in foreign countries.

In China, as a result of the reforms that started in 1978, the nation decided to carry a foreign market policy under the control of the government. This Chinese implementation, also known as the controlled market system, financial affairs are carried in cooperation with the foreign market. Additionally, sustainable efficiency of economy is provided by the nation and the system goes through a series of reform. Chinese economy, currently ranking second in economy worldwide, has become one of the world's giant by developing itself with controlled market system after getting into foreign market. Chinese economy, the economic growth of which was around $10 \%$ in 2000 's, adopted a growth model based on export attracted a great amount of investment and achieved to increase its financial growth. It is observed that with the increase of national economic growth rate, current account deficit levels also increase correspondingly. During this period, while China had a strong growth policy, it achieved an extremely difficult objective by having current account surplus on the contrary of other countries. However, the literature focuses on the countries which have current account deficit while increasing their economic growth. In our study, aforementioned exceptional case of China will be studied via econometric analysis and its related exemplary performance will be examined.

Annual data of Turkish economy between the period of 1990-2015 is used in this study. Within the scope of this sample, correlation and causality relation between economic growth and current account deficit is studied with time-series techniques. Within the study, after introduction, following sections take place: Literature Review, Current Account Balance Performance Undisguised with Growth: China, Methodology, Econometric Analysis and Conclusion.

\section{Literature Review}

According to Calderon, Chong and Loazya (1999), casual changes in the growth rate of national income increases the current accounts deficit. According to the results of studies, in which the current account deficit is the dependent variable, $11 \%$ of increase in growth causes $0.21 \%$ increase $\mathrm{n}$ current account deficit. Moreno-Brid (1999) examined the relation between current account balance for 1950-1996 Mexican economy and economic growth by using Balance of Payments Constrained Model (BPC). Writer has associated the deceleration in economic growth rate with the long-term increase in income elasticity of import.

Chin and Prasad (2000) studied the determinants of current account balance for seventy-one developed and developing countries of 1971-1995 period with Least Squares and Fixed Effects Methods and asserted that there is weak relation between current account balance and growth rate of developed and developing countries.

Kandil and Greene (2002) used co-integration test and Error Correction Method (ECM) in order to test the relation between economic growth and current account balance for American economy in 1960-2000. Separating their study into three periods, Kandil and Greene paid regard to both quarterly and annual data of 1960-2000 and only the quarterly data for the period of 19902000 and 1995-2000. They stated that the increase in real GDP alerted the import, corrupting the current account balance and thereby caused increase in current account deficit.

Aristovnik (2007), researched the determinants of current account deficits of thirteen central and East Europe countries, having economy in transition, with FEM method, using the annual data of 1992-1999 and detected a week relation between growth rate and current account deficit. Aristovnik determined that $1 \%$ of increase in growth rate caused $0.30 \%$ of increase in current account deficit. According to Van den Berg and Lewer (2007), causality relation between economic 
growth and export in an outward-oriented economy is in the way that export indirectly affects the economic growth in a positive way. As a result of the increase in export, resources will be shifted from ineffective non-business industries towards the industry of export and efficient use of resources will lead to increase in efficiency and economic growth. Increase in export will cause pressure through international competition and as a result, emerging technologies will be followed, research and development will increase, more effective management techniques, entrepreneurship activities, abilities and competence of learning by doing will develop and accordingly, the efficiency will improve and economic growth will increase.

Malik, Chaudhry, Sheikh and Farooqi (2010), studied the relation between tourism, economic growth and current account deficits for the period of 1969-2007 for short and long term in Pakistan with Johansen co-integration test and ECM analysis. The writers concluded that tourism has a positive effect on economic activities and thereby on the economic growth of Pakistan. Results of the study has also shown that there is a long-term relation between the number of tourists, economic growth rate and current account deficit. In the study, it is highlighted that related to the increase in touristic activities, decrease in current account deficits will increase the economic growth rate.

Çakır (2012) tested the relation between economic growth and current account deficit in Turkey monthly and quarterly for the period of 1992-2011 with Granger Causality Analysis. While bidirectional causality relation is detected between growth and current deficit in monthly data set, in quarterly data set, a causality relation is detected from the rate of growth towards current account balance.

Akbaş (2012) studied whether there is a relation between current account deficit, short-term capital flows and economic growth in 20 OECD countries between the years of 1990-2010. In the study, he used Panel Co-integration and Causality analysis. As a result of the co-integration, it is determined that there is co-integration between three variables. As a result of the causality analysis, it is determined that there is a bidirectional causality relation between current account deficit and economic growth. Kandemir (2015) used quarterly data of 1998-2013 period in order to determine the relation between current account deficit and growth. Granger Causality and Least Squares tests are used in this study. As a result, a bidirectional causality detected between growth and current account deficit.

\section{Current Account Balance Performance Undisguised with Growth: China}

In $18^{\text {th }}$ and $19^{\text {th }}$ century, Industrial Revolution in England was a milestone for the world and balance of power began to change in the world. In $20^{\text {th }}$ century, with the appearance of globalization concept, new rules were brought into world economy and nations had to renew their strategies in order to keep up with these rules. Economy of China, which can be considered as one of these countries, had industrialization strategy based on export with the reforms it conducted after 1978.

People's Republic of China is one of the most crowded countries with a population more than 1 billion 300 million. In such a populated country, it is expected to have maximum consumption rate, however; Chinese people economize $25 \%$ of their income and they are a lowconsuming nation. It is easy to acquire cheap work force as there are many people in China. Thereby, China, being able to produce high number of goods with low production costs, can export a major part of its goods.

As can be seen in Table 1, product and service export in China continuously increased and between 2000-2015, balance of payments had constant current surplus. The reason for that, as mentioned above, is China's producing more than it consumes and exporting what it produces. However, between the specified years, increase in product and service import is also seen. This increase causes due to the fact that the import conducted to be re-exported in China has major share in economy. 
Züngün, D. (2016). Longing for economic growth without current account deficit: Chinese model. Journal of Human Sciences, 13(3), 3927-3938. doi:10.14687/jhs.v13i3.4079

Table 1: Balance of Payments Items and Current Account Balance Amount (US Dollar) in China between 2000-2015

\begin{tabular}{|l|l|l|l|l|}
\hline & $\begin{array}{l}\text { Product and Service } \\
\text { Import }\end{array}$ & $\begin{array}{l}\text { Product and Service } \\
\text { Export }\end{array}$ & $\begin{array}{l}\text { Unrequited } \\
\text { Transfers }\end{array}$ & $\begin{array}{l}\text { Current Account } \\
\text { Balance }\end{array}$ \\
\hline $\mathbf{2 0 0 0}$ & 318.143 .506 .804 & 331.174 .597 .120 & 6.311 .305 .000 & 20.431 .615 .376 \\
\hline $\mathbf{2 0 0 1}$ & 347.539 .636 .506 & 350.951 .222 .616 & 8.492 .313 .080 & 17.405 .274 .979 \\
\hline $\mathbf{2 0 0 2}$ & 434.308 .191 .640 & 444.041 .696 .570 & 12.984 .445 .070 & 35.421 .968 .224 \\
\hline $\mathbf{2 0 0 3}$ & 575.544 .881 .744 & 568.410 .302 .220 & 17.448 .942 .294 & 43.051 .582 .815 \\
\hline $\mathbf{2 0 0 4}$ & 709.620 .753 .130 & 707.121 .606 .684 & 22.898 .188 .613 & 68.940 .960 .618 \\
\hline $\mathbf{2 0 0 5}$ & 800.698 .123 .508 & 873.047 .487 .472 & 23.865 .499 .352 & 132.378 .493 .930 \\
\hline $\mathbf{2 0 0 6}$ & 936.186 .958 .274 & 1.091 .940 .057 .586 & 28.067 .501 .500 & 231.843 .041 .063 \\
\hline $\mathbf{2 0 0 7}$ & 1.064 .327 .903 .771 & 1.312 .377 .733 .199 & 37.102 .286 .294 & 353.182 .677 .260 \\
\hline $\mathbf{2 0 0 8}$ & 1.124 .344 .228 .945 & 1.439 .924 .080 .256 & 43.155 .952 .500 & 420.568 .516 .075 \\
\hline $\mathbf{2 0 0 9}$ & 1.169 .422 .129 .128 & 1.284 .330 .941 .726 & 31.658 .747 .086 & 243.256 .568 .043 \\
\hline $\mathbf{2 0 1 0}$ & 1.380 .920 .299 .700 & 1.603 .944 .171 .550 & 40.685 .856 .973 & 237.810 .389 .738 \\
\hline $\mathbf{2 0 1 1}$ & 1.602 .138 .736 .158 & 1.829 .168 .127 .062 & 24.510 .589 .593 & 136.096 .761 .650 \\
\hline $\mathbf{2 0 1 2}$ & 1.715 .617 .071 .262 & 1.943 .129 .638 .688 & 3.433 .702 .055 & 215.391 .747 .425 \\
\hline $\mathbf{2 0 1 3}$ & 1.903 .709 .989 .954 & 2.120 .109 .874 .687 & -8.733 .482 .705 & 148.203 .949 .948 \\
\hline $\mathbf{2 0 1 4}$ & 2.079 .960 .939 .040 & 2.263 .932 .783 .215 & 1.446 .116 .617 & 277.433 .901 .970 \\
\hline $\mathbf{2 0 1 5}$ & 2.160 .639 .236 .124 & 2.220 .841 .681 .785 & -8.676 .872 .900 & 330.602 .206 .873 \\
\hline $\mathbf{S 0 u}$
\end{tabular}

Source: OECD, http://stats.oecd.org/index.aspx\# , (Date Accessed: 31.08.2016)

Increase in Chinese import and export, in other words, growth in its foreign trade, has bidirectional effect in world market: Firstly; China changed the foreign trade balance of other countries with its major growth in export. Secondly; it imported raw material from other countries in order to increase its economic development and production potential and thereby, increased the market price of inputs. The most explicit example for that can be seen in the increase of oil price all over the world. China ranks second in the import of oil. China consumes more than $1 / 3$ of aluminum, iron, steel and leather production in the world. In fact, supply problems began to occur for these raw materials (Turkish Asian Strategic Studies Center, 2011). Today, 80\% of ventilation systems, $70 \%$ of mobile phones and 60\% of shoes are manufactured in China (Şenerdem, 2016).

In the world, besides being a country which can export a major part of its products manufactured with low cost and saving, China is a country that can also control its domestic currency. China managed to keep its domestic currency, Yuan, at a low rate and when compared to its long-standing rival, United States of America's Dollar, it allowed limited appreciation of its currency. As a result of all these developments, Chinese economy has continuously grown with such a rate as $10 \%$.

As shown in Table 2, while Chinese economy had 8\%-9\% of growth in the beginning of 2000 's, its growth rate increased to 10\%'s in 2003 and reached up to $14 \%$ in 2007 . Remaining stable for a while after 2007, Chinese economic growth rate was around 7\% between 2012-2014 and decreased to $6,9 \%$ in 2015 . The reason of this decrease is the appreciation of dollar in 2014, depreciation of currencies of developing countries and China's slowly losing its competition superiority over these countries. Thereby, China had a decrease in export, decided to change its growth structure and declared that it would turn towards domestic consumption. As a result of this progress, decrease in export and economic growth indirectly affected each other. 
Table 2: Growth Rate of China between 2000-2015 (\%)

\begin{tabular}{|l|l|}
\hline Years & $\begin{array}{l}\text { Economic } \\
\text { Growth Rate (\%) }\end{array}$ \\
\hline $\mathbf{2 0 0 0}$ & 8.431 \\
\hline $\mathbf{2 0 0 1}$ & 8.305 \\
\hline $\mathbf{2 0 0 2}$ & 9.085 \\
\hline $\mathbf{2 0 0 3}$ & 10.022 \\
\hline $\mathbf{2 0 0 4}$ & 10.077 \\
\hline $\mathbf{2 0 0 5}$ & 11.348 \\
\hline $\mathbf{2 0 0 6}$ & 12.686 \\
\hline $\mathbf{2 0 0 7}$ & 14.199 \\
\hline $\mathbf{2 0 0 8}$ & 9.621 \\
\hline $\mathbf{2 0 0 9}$ & 9.236 \\
\hline $\mathbf{2 0 1 0}$ & 10.629 \\
\hline $\mathbf{2 0 1 1}$ & 9.487 \\
\hline $\mathbf{2 0 1 2}$ & 7.748 \\
\hline $\mathbf{2 0 1 3}$ & 7.685 \\
\hline $\mathbf{2 0 1 4}$ & 7.269 \\
\hline $\mathbf{2 0 1 5}$ & 6.900 \\
\hline
\end{tabular}

Source: OECD, http://stats.oecd.org/index.aspx\#, (Date Accessed: 31.08.2016)

However, within these 15 years of addressed period, the most important finding, which drew attention and became the subject of our study, is that although China had such a growth rate of 9,5 within this period, it steadily had current account surplus. Such growth stories, observed in Turkey, Brazil and many other countries, mostly result in deficit in current balance and these countries consider the deficit problem in current balance as a natural result of positive developments in economy, believed to be achieved through growth, and they try to launch it as a natural result to the public. Thereby, performance of China in particularly the last 15 years and aforementioned indicators are good examples for countries which try to disguise behind the growth, avoid or suppress the problem of current account deficit. Because China, even when it reached the level of 14\% in 2007, which can be considered as a record rate, has 353 billion dollar of current surplus. The main reason of the surplus is that besides having a high level of saving in the country, the level of production is also very high and extra production is exported, leading to current surplus. Additionally, as we can encounter many similar examples in other economies, positive feedback in economy due to growth, cannot change the consumption habit of people and preventing this incident from negatively affecting the foreign trade balance played an important role in keeping the current balance stable and maintain it consistently without being disguised under the excuse of growth.

\section{METHODOLOGY}

\subsection{Concept of Stability in Time Series and Unit Root Tests}

Time series are acquired when the observed variants with value are ranged by time. Time series analysis ensures being able to predict for future with the help of observation values of previous periods (Kaplan, 2009: 35). The first thing to do in time series analysis is to detect the stability of the series. If the series is not stable, the reasons for that are examined and necessary methods are applied in order to acquire the stability. Most of the time series do not have stability feature. Many series mostly have either decreasing or increasing trend (Kutlar, 2000: 12-13).

If a time series is stable, its average, variance and common variance in various delays are always the same (Gujarat1, 1999: 713). In other words, average or variance of any time series such as $\mathrm{X}_{\mathrm{t}}$ is stable in time and its covariance is not based on time but time period between only the two 
periods, this time series is stable. If one or more of these conditions are not met, $\mathrm{X}_{\mathrm{t}}$ series is not stable (Charemza and Deadmen, 1999: 85). Using unstable time series causes major problems. Models, which are set with time series including stochastic and deterministic trend, show spurious regression results. Additionally, auto-correlations deviate from zero or diverges from zero when the delays increase (Utkulu, 1993: 304-305).

In order to examine the stability, firstly a graphic of the series can be created and the progress can be analyzed. By looking at the graphic, one can have an idea however cannot reach an exact conclusion. For that reason, different methods are discovered in order to analyze the stability. The most known method is the unit root tests. In literature, most used methods are Augmented Dickey-Fuller Test and Philips-Perron Unit Root Tests.

$$
\mathrm{X}_{\mathrm{t}}=\mathrm{c}_{\mathrm{o}}+\mathrm{j} \cdot \mathrm{X}_{\mathrm{t}-1}+\mathrm{e}_{\mathrm{t}}
$$

(1)

In the equation (1), if $|j|<1, X_{t}$ series is stable, if $|j|=1, X_{t}$ series is unstable. For time series, most of which are economic, it is applicable that autoregressive coefficient $j$ is one or lower. $j>1$ is not economically logical. In autoregressive equation of (1), $j=1$ is known as "variances stable process" and most of the economic time series is considered as variances stable process. In such a process, when $j=1, X_{t}$ series is first degree integrated (Utkulu, 1993: 309).

\subsection{Causality Analysis}

In order to display the causality relation between variables, Granger causality analysis is used. Equations used in Granger causality test is shown in (2) and (3):

$$
\begin{aligned}
& Y_{t}=-\sum_{j=1}^{m} a_{11 j} Y_{t-j}-\sum_{j=1}^{m} a_{12 j} X_{t-j}+u_{t 1} \\
& X_{t}=-\sum_{j=1}^{m} a_{21 j} Y_{t-j}-\sum_{j=1}^{m} a_{22 j} X_{t-j}+u_{t 2}
\end{aligned}
$$

In the equation, whether the $\mathrm{X}$ causes $\mathrm{Y}$ is found by examining the hypothesis of;

And whether the $\mathrm{Y}$ causes $\mathrm{X}$ is found by examining the hypothesis of;

$$
\mathrm{H}_{0}(\mathrm{X}=>\mathrm{Y}): \mathrm{a}_{12,1}=\ldots \ldots .=\mathrm{a}_{12, \mathrm{~m}}=0
$$

$$
\mathrm{H}_{0}(\mathrm{Y}=>\mathrm{X}): \mathrm{a}_{21,1}=\ldots \ldots=\mathrm{a}_{21, \mathrm{~m}}=0
$$

If the probabilities found as the result of the test are lower than $10 \%, 5 \%$ or $1 \%$ significance level, the $\mathrm{H}_{0}$ hypothesis stating " $\mathrm{X}$ is not the cause of $\mathrm{Y}$ " or " $\mathrm{Y}$ is not the cause of $\mathrm{X}$ " is rejected. In short, either $\mathrm{X}$ is the Granger cause of $\mathrm{Y}$ or $\mathrm{Y}$ is the Granger cause of $\mathrm{X}$. However, if the probabilities are higher than $10 \%, 5 \%$ or $1 \%$ significance level, the $\mathrm{H}_{0}$ hypothesis stating " $\mathrm{X}$ is not the cause of $\mathrm{Y}$ " or " $\mathrm{Y}$ is not the cause of $\mathrm{X}$ " is accepted. In short, neither $\mathrm{X}$ is the Granger cause of Y nor Y is the Granger cause of X (Tar1, 2011:437).

\subsection{Regression and Correlation Analysis}

When analyzing the relationship between two or more variables, regression and correlation methods are used. While in regression the form of the relationship between variables are tried to be determined numerically, in correlation the degree of these relationships are determined.

The linear relationship between two variables can be formulated including one dependent variable and one independent variable as follows:

$$
Y=\alpha+\beta X+\varepsilon
$$

In the equation (4), $\mathrm{Y}$ is dependent variable, $\mathrm{X}$ is independent variable and $\varepsilon$ is error term. The method generally used in obtaining the regression equation is Least Squares Method. The essence of Least Squares Method is based on the situation that the total number of squares of deviations from regression line of the value of $Y$ is minimum. In that sense, Least Squares Method regression line represents the same thing with arithmetic mean (Çakıcı et al., 2003:139-167).

On the other hand, the correlation coefficient is measurement that shows the degree of the relationship between variables. When the value is between 0 and 1 , there is positive correlation; when the value is between 0 and -1 , there is negative correlation. When the correlation coefficient is 0 , there is no relationship between variables; when the correlation coefficient is 1 or -1 , there is a 
complete correlation between variables. If the correlation coefficient is between 0 and 0.49 , the relationship is weak; if it is between 0.50 and 0.74 , the relationship is average; and if it is between 0.75 and 1 , the relationship is strong. The symbol of the correlation coefficient depends on the symbol of $\beta$ coefficient in the regression equation. If $\beta$ is positive, the correlation is positive; if $\beta$ is negative, the correlation is negative (Akkaya and Pazarlıoğlu, 1998:85-86).

\section{ECONOMETRIC ANALYSIS}

\subsection{Data Set and Variables}

In this study, the relationship between economic growth and current account balance in China between 2000 and 2015 has been analyzed via time series analysis and the numerical results which were found have been evaluated. In the study, annual economic growth and annual current account balance data have been used. The variables used in the application have been compiled from the database of OECD (Organization for Economic Co-operation and Development) website. In the study, first of all, the logarithms of the values have taken in order to omit the small fluctuations that time series can display. After that, Augmented Dickey Fuller test (ADF) and Phillips Peron test (PP) have been done so as to determine if the values belonging to two variables are stationary or not. Then, Granger Causality test has been done in order to detect the causality relationship between variables; finally, Regression Analysis and Correlation Analysis have been applied so as to determine the direction and the degree of the relationship.

The changes of these data in time are seen in Figure 1. The GDP used in the analyses is abbreviation of Economic Growth (Gross Domestic Product); the CAB used in the analyses is abbreviation of Current Account Balance.

\section{Figure 1. GDP and Current Balance Graphics}


Between the years of 1990-2015, when series, displaying GDP and CAB data, are examined, it is seen that both graphics maintained with increase until 2007, reached its peak in 2007 and following that, had a decreasing trend. As of 2013, it draws attention that in exchange for the increase of current account balance, economic growth has decreased.

\subsection{Unit Root Tests}

The fact that the series have unit roots means that it is not stable. When the stable data of ADF and PP test statistics are examined, it is seen that GDP and CAB series do not have a stable structure on the level and do not range around a certain average. After the first subtraction, it is seen that the test statistics of variables are bigger than critical values determined by Mackinnon as the absolute value. Thereby, after the first subtraction of GDP and CAB series, so to say, in I (1), it can be said that it provides stability hypothesis (see Table 4 and Table 5). Graphics of stable series, subtracted from $1^{\text {st }}$ degree, are shown in Figure 2. 
Figure 2. Graphic of Subtracted GDP and CAB Series

D(LOGGDP)

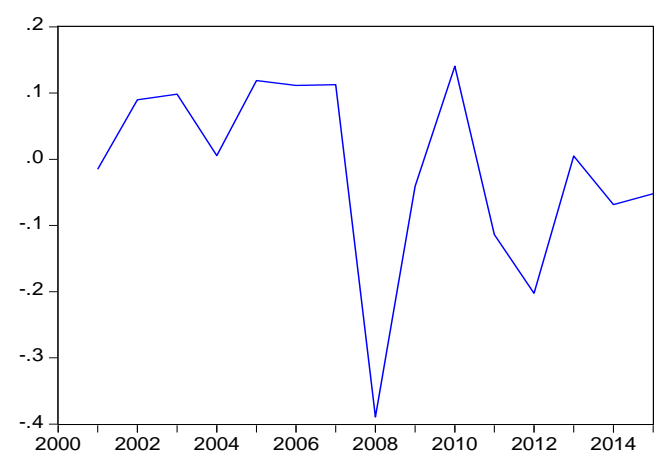

$\mathrm{D}($ LOGCAB)

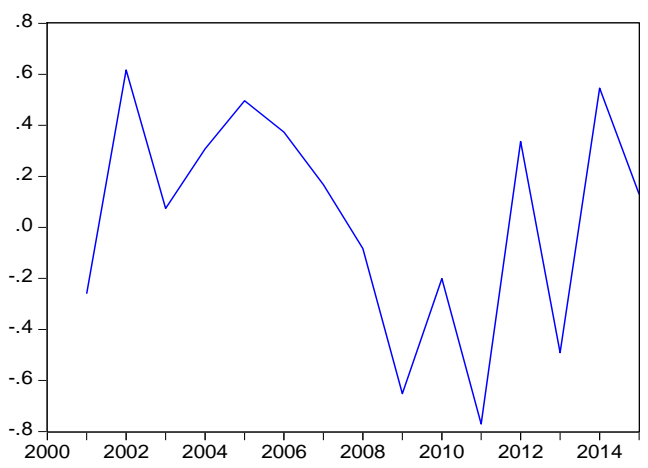

Table 3: ADF Unit Root Test Results

\begin{tabular}{|c|l|l|l|}
\hline & & \multicolumn{2}{|c|}{ ADF - t Statistics } \\
\hline Variables & $\begin{array}{l}\text { MacKinnon } \\
\text { Critical } \\
\text { Values }\end{array}$ & $\begin{array}{l}\text { Level } \\
\text { Values }\end{array}$ & $\begin{array}{l}\text { First } \\
\text { Subtraction }\end{array}$ \\
\hline GDP & $\begin{array}{l}\% 1=-3.9591 \\
\% 5=-3.0811 \\
\% 10=-2.6813\end{array}$ & $-1.0051(0)$ & $-3.3581(0)^{* *}$ \\
\hline CAB & $\begin{array}{l}\% 1=-4.0579 \\
\% 5=-3.1199 \\
\% 10=-2.7011\end{array}$ & $-1.6189(2)$ & $-3.6189(3)^{* *}$ \\
\hline
\end{tabular}

NOTE: Values in brackets provides information about the delay length selected according to SCI criteria. Critical values for $\mathrm{ADF}$ are acquired by MacKinnon (1996). $* * * \mathrm{p}<.01, * * \mathrm{p}<.05,{ }^{*} \mathrm{p}<.1$.

Table 4: PP Unit Root Test Results

\begin{tabular}{|c|l|l|l|}
\hline & & \multicolumn{2}{|c|}{ PP -t Statistics } \\
\hline Variables & $\begin{array}{l}\text { MacKinnon } \\
\text { Critical } \\
\text { Values }\end{array}$ & $\begin{array}{l}\text { Level } \\
\text { Values }\end{array}$ & $\begin{array}{l}\text { First } \\
\text { Subtraction }\end{array}$ \\
\hline GDP & $\begin{array}{l}\% 1=-3.9591 \\
\% 5=-3.0811 \\
\% 10=-2.6813\end{array}$ & $-1.0425(2)$ & $-3.3394(6) * *$ \\
\hline \multicolumn{4}{c|}{$\% 1=-3.9591$} \\
& $\begin{array}{l}\% 5=-3.0811 \\
\% 10=-2.6813\end{array}$ & $-1.6742(2)$ & $-3.6204(2)^{* *}$ \\
\hline $\begin{array}{l}\text { NOTE: Values in brackets provides information about } \\
\text { the delay length selected according to SCI criteria. Critical } \\
\text { values for PP are acquired by Mackinnon (1996). } \\
* * * \mathrm{p}<.01, * * \mathrm{p}<.05, * \mathrm{p}<.1 .\end{array}$ \\
\hline
\end{tabular}




\subsection{Granger Causality Test}

"Granger Causality Test" is developed by Granger in order to test whether the variable in a model, created in order to estimate a variable, cause another one. Causality relation between variables are explained through this test. Delay length in causality analysis is determined by using Akaike Information Criterion and proper delay length is set as 2 . Acquired results are presented in Table 5.

\section{Table 5: Granger Causality Test Results}

\begin{tabular}{|l|l|l|}
\hline Hypothesis & F-statistics & Probability \\
\hline CAB is not the cause of GDP. & 0.4847 & 0.0414 \\
\hline GDP is not the cause of CAB. & 1.2455 & 0.0352 \\
\hline
\end{tabular}

According to Granger Causality Test results, Ho hypothesis (with 0.0414) claiming that $\mathrm{CAB}$ is not the Granger cause of GDP and Ho hypothesis (0.0352) claiming that GDP is not the Granger cause of $\mathrm{CAB}$ is rejected with $5 \%$ of significance level. Thereby, a bidirectional causality relation is deduced between economic growth and current account balance. This acquired result supports Çakır (2012), Akbaş (2012) and Kandemir (2015).

\subsection{Correlation and Regression Analysis}

Before regression analysis, causality relation between GDP and CAD should be determined. If there is no causality relation between these two series, the result of regression analysis would not make any sense economically although it is meaningful statistically. In Table 6, results of regression analysis are displayed.

Table 6. Regression Analysis Results (Dependent variable = CAB)

\begin{tabular}{|c|l|}
\hline VARIABLES & \\
\hline STABLE & 3.9201 \\
& $(2.8333)^{*}$ \\
\hline GDP & 0.3296 \\
& $(3.7214)^{*}$ \\
\hline $\mathrm{R}^{2}$ & 0.5972 \\
\hline DW & 1.4137 \\
\hline F ist.(Prob.) & 0.0022 \\
\hline
\end{tabular}

$\% 1$.

NOTE: Numbers in brackets are t statistics. ${ }^{*}$ symbol means significance in the level of

In Table 6, the results of regression analysis are given by using the equation (4). Accordingly; as the probability values of coefficients are lower than $1 \%, \mathrm{H}_{0}$ : rejected, $\mathrm{H}_{1}$ : accepted and the coefficients are significant. For the total significance of the model, probability $\mathrm{F}$ is considered and as it is lower than $1 \%, \mathrm{H}_{0}$ : rejected and $\mathrm{H}_{1}$ : accepted; so the model is significant. It is seen that " $\mathrm{t}$ " value belonging to economic growth is statistically significant in the level closer to $1 \%$ and the direction of the relationship is positive. Also, the determination coefficient of the model $\left(R^{2}\right)$ is found in a rate which is close to high levels such as 0.59 . on the other hand, the value of D.W (Durbin - Watson) statistic which obtained from regression analysis (1.41) indicates that there isn't any serial correlation problem between the error terms of the model.

When the results of regression analysis are evaluated in terms of economics, it is understood that the relationship between growth and current account balance in China has a positive direction. The positive symbol of GDP coefficient indicates this. In the period of 1990 $2015,1 \%$ increase in economic growth is expected to create a $0.32 \%$ increase in current account 
balance. However, it is seen that this rate is rather low. In addition, while the growth is fixed, current account balance is expected to be 3.92 .

We can see the positive relationship between variables obtained from Regression Analysis also in Correlation Analysis (see. Table 7).

Table 7. Correlation Analysis Results
\begin{tabular}{|c|c|c|}
\hline Variables & GDP & CAB \\
\hline GDP & 1.0000 & 0.7051 \\
\hline CAB & 0.7051 & 1.0000 \\
\hline
\end{tabular}

When the data in Table 7 is examined, it can be said that the correlation is positive $(0.7051)$ between current account balance and economic growth and that there is a strong relation between them.

\section{Conclusion}

Unlike many other countries, while Chinese economy has a high growth rate, the economy doesn't have current account deficit as expected; contrary it has current account surplus. This situation shows the argument which is common in the literature stating that as the economic growth rate increases, the current account deficit increases is not valid for the Chinese economy. Since the developing countries such as Turkey and Brazil do not have sufficient amount of intermediate good, their wish to grow more leads them to their act of more importation; and this results in the increase in their current account deficit. However, Chinese economy stands out as a great economy as the economy doesn't have a current account deficit problem. The reason is that China enhances its economic growth by increasing the amount of investment inside the country in a big-scale with its export-oriented growth model. Also, having a great amount of labor force is another factor for Chinese economy to become successful. Finally, current account surplus in the country is created by exporting surplus production which is the result of high level of savings and high level of output in the country.

In the study, the relationships between economic growth and current account balance have been analyzed via Granger Causality Test, Regression Analysis and Correlation Analysis by using annual data for 2000-2015 periods. In that sense, at first, the subject variables have been put to ADF and PP Unit Root Tests and they were found stationary in their first subtraction. As the Granger Causality Test result of the study which covers 2000-2015 periods for China, a bidirectional causality relationship between economic growth and current account balance has been found. It is ascertained in the Regression Analysis that 1\% increase in economic growth creates $0.32 \%$ increase in current account balance. Finally, it is determined with Correlation Analysis that there is a positive and strong relationship between current account deficit and growth. The results that are found corroborate the studies of Çakır (2012), Kandemir (2015) and many other studies in the literature. This study reveals that although the economic growth in Chinese economy is decent, current account balance creates surplus unlike many other countries.

\section{References}

Akbaş, Y. E. (2012). Ekonomik Büyüme, Cari Açık Ve Kısa Vadeli Sermaye Akımları Arasındaki Karşılıklı İlişkinin İncelenmesi: OECD Ülkeleri Üzerine Bir Araştırma. [Examination of Interrelation between Economic Growth, Current Account Deficit and Short-Term Capital Flows: A Research on OECD Countries.] (Unpublished PHD Dissertation). İnönü University Institute of Social Sciences. 
Züngün, D. (2016). Longing for economic growth without current account deficit: Chinese model. Journal of Human Sciences, 13(3), 3927-3938. doi:10.14687/ihs.v13i3.4079

Akkaya, Ş. \& Pazarlığlu, M. V., (1998). Ekonometri-1 [Econometry-1], Anadolu Printing, İzmir, 4. Edt.

Aristovnik, A. (2007). Short- and medium-term determinants of current account balances in Middle East and North Africa countries. The Business Review, 7 (2), 251-264.

Calderon, C., Chong, A., \& Norman, L. (1999). Determinants of Current Account Deficits in Developing Countries. Central Bank of Chile Working Papers .

Charemza, W.W. \& Deadman D.F. (1999). New Directions in Econometric Practice, 2. Edt, USA: Edward Publishing.

Chinn, M., \& Parasad, E. S. (2000). Medium Term Determinants of Current Accounts in Industrial and Developing Countries: An Empirical Exploration. NBER Working Paper .

Çakıcı, M., Oğuzhan, A. \& Özdil, T. (2003), Temel İstatistik-2 [Basic Statistics-2], Özal Printing, İstanbul, 4. Edt

Çakır, P. (1999). Türkiye'nin Turizm Gelirlerinin Ödemeler Dengesine Katkısının Analizi. [Analysis of Turkish Tourism Income Support in Balance of Payments] Eskişehir: Anadolu University Press Edt. No: 1119.

Gujaratı, D.N. (1999), Temel Ekonometri, [Basic Econometrics], (Trans. by: Ü. Şenesen, G.G. Şenesen), İstanbul: Literatür Press.

Kandemir, K. (2015). Cari Açık Üzerinde Ekonomik Büyümenin Etkisi: Türkiye Uygulaması. [Effect of Economic Growth on Current Account Deficit: Turkish Implementation]. (Unpublished Post-Graduate Thesis) Adnan Menderes University Institute of Social Sciences.

Kandil, M., \& Greene, J. (2002). The Impact of Cyclical Factors on the US Balance of Payments. IMF Working Paper , 1-43.

Kaplan, F. (2009). Türkiye'de Reel Döviz Kurlarındaki Oynaklığın İssizlik Ve Büyüme Oranları Üzerine Etkileri. [Effect of Volatility in Turkish Real Exchange Rates on Growth Rate]. (Unpublished Post-Graduate Thesis). Isparta: Süleyman Demirel University Institute of Social Sciences.

Kibritçioğlu, A. (1998). İktisadi Büyümenin Belirleyicileri ve Yeni Büyüme Modellerinde Beşeri Sermayenin Yeri. [Position of Human Capital in Determinants of Economic Growth and New Growth Models] A.Ü. Faculty of Political Sciences Magazine. 53 (1-4): 207-230.

Kutlar, A. (2000). Ekonometrik Zaman Serileri Teori ve Uygulama. [Econometric Time Series Theory and Implementation]. Ankara: Gazi Bookstore.

Malik, S., Chaudhry, I., Sheikh, M., \& Farooqi, F. (2010). Tourism, Economic Growth and Current Account Deficit in Pakistan: Evidence from Co-Integration and Causal Analysis. European Journal of Economic, Finance and Administrative Sciences , 22, 21-31.

Moreno-Brid, J. (1999). Mexico's Economic Growth and the Balance of Payments Constraint: A Cointegration Analysis. International Review of Applied Economics, 13 (2), 149-159.

OECD. (2016). Economic Outlook No 99 - June 2016 : By country. http://stats.oecd.org/index.aspx\# (1.9.2016).

Seyidoğlu, H. (2003). Uluslararası İktisat. [International Economy] İstanbul: Güzem Can Press.

Şenerdem, E. (2016, Ocak 5). Çin kaynaklı şok dalgaları dünyayı ve Türkiye'yi nasıl etkileyecek?. [How will China based shockwaves will affect the world and Turkey?]. http://www.bbc.com/turkce/ekonomi/2016/01/160105_cin_ekonomi_donusum. (31.09.2016). 

Sciences, 13(3), 3927-3938. doi:10.14687/jhs.v13i3.4079

Tar1, R. (2011). Ekonometri. [Econometry]. Kocaeli: Umuttepe Press.

Turkish Asian Strategic Research Center. (2011, June 21). Çin Ekonomisinin Yapisal Dönüşümü ve Gelişmekte Olan Ülkeler Açisindan Sonuçlari [Structural Transformation of Chinese Economy and Its Results In Terms of Developing Countries]. http://www.tasam.org/trTR/Icerik/3170/cin_ekonomisinin_yapisal_donusumu_ve_geli smekte_olan_ulkeler_acisindan_sonuclari (31.09.2016).

Utkulu, U., (1993), Türkiye'nin Dış Ticareti ve Değişen Mukayeseli Üstünlükler [Foreign Trade of Turkey and Changing Comparative Superiorities], İzmir: Dokuz Eylül University Press

Van den Berg, H., \& Lewer, J. (2007). International Trade and Economic Growth. London: M. E. Sharpe Incorparation. 